\title{
Stage IIIB Gallbladder Cancer AJCC v8
}

National Cancer Institute

\section{Source}

National Cancer Institute. Stage IIIB Gallbladder Cancer A/CC v8. NCI Thesaurus. Code C134674.

Stage IIIB includes: T1-3, N1, M0. T1: Tumor invading the lamina propria or muscular layer. T2: Tumor invading the perimuscular connective tissue on the peritoneal side, without involvement of the serosa (visceral peritoneum); or tumor invading the perimuscular connective tissue on the hepatic side, with no extension into the liver. T3: Tumor perforating the serosa (visceral peritoneum) and/or directly invading the liver and/or one other adjacent organ or structure, such as the stomach, duodenum, colon, pancreas, omentum, or extrahepatic bile ducts. N1: Metastases to one to three regional lymph nodes. M0: No distant metastasis. (AJCC 8th ed.) 